\title{
ЗАСОБИ ВИРАЖЕННЯ НЕГАТИВНИХ ЕМОЦІЙ У СУЧАСНИХ ПУБЛЦЦИСТИЧНИХ ТЕКСТАХ (на матеріалі статей, опублікованих у журналі New Yorker та газеті Украӥнська правда)
}

\author{
ВІРА СЛІПЕЦЬКА \\ Дрогобицький державний педагогічний університет імені Івана Франка, \\ Дрогобич - Україна \\ vslipetska@ukr.net; ORCID: 0000-0002-2569-0197 \\ SPOSOBY WYRAŻANIA NEGATYWNYCH EMOCJI \\ WE WSPÓŁCZESNYCH TEKSTACH PUBLICYSTYCZNYCH \\ (na materiale artykułów opublikowanych \\ w czasopiśmie New Yorker i gazecie Українська правда) \\ WIRA SLIPECKA \\ Państwowy Uniwersytet Pedagogiczny imienia Iwana Franki w Drohobyczu, \\ Drohobycz — Ukraina
}

STRESZCZENIE. W artykule dokonano analizy sposobów wyrażania negatywnych emocji gniewu, nienawiści, oburzenia we współczesnych ukraińskich oraz angielskich tekstach publicystycznych. Bezpośrednia nominacja emocji, wyrazy-wykrzykniki, brutalna leksyka, znaki wykrzyknienia, metaforyczne przeniesienia, negatywnie zabarwione partykuły to środki wyrażenia negatywnych emocji.

Słowa kluczowe: środki językowe, negatywne emocje, werbalizacja, tekst publicystyczny, nominacja bezpośrednia, brutalna leksyka.

\section{MEANS OF EXPRESSION OF NEGATIVE EMOTIONS \\ IN MODERN PUBLICISTIC TEXTS \\ (based on the articles published in New Yorker, Ukrainska Pravda)}

\section{VIRA SLIPETSKA}

Drohobych Ivan Franko State Pedagogical University, Drohobych — Ukraine

ABSTRACT. The article focuses on the analysis of the language means of the negative emotions verbalization in modern publicistic texts in Ukrainian and English. A direct nomination of emotions, interjections, vulgar words, exclamatory marks, metaphors, negative particles are considered to be the main means of the negative emotions expression.

Key words: language means, negative emotions, verbalization, publicistic text, direct nomination, vulgar words.

априкінці XX - на поч. XXI ст., коли факти й події довкілля (війни, теракти, підвищений рівень злочинності, велика кількість біженців, вимушених переселенців і под.) перенасичені негативними оцінками, емоціями, увага дослідників зосередилася на вивченні різних аспектів наслідків комунікації, що зумовлюють негативні відчуття, негативне сприйняття дійсності й негативне іiі бачення. Незважаючи на прагнення людини до позитиву, негатив завж- 
ди приваблює більше, що зумовлено природою людської психіки, відображеної в законах комунікації (Див. праці Т. Космеди ${ }^{1,2}$ та ін.).

На сучасному етапі розвитку лінгвістики вивчення засобів вираження емоцій, емоційної оцінки довкілля посідає особливе місце. Така зацікавленість пояснюється передусім тим, що емоції й оцінка як універсальні філософські, лінгвістичні й психологічні категорії є основними компонентами процесу комунікації. В останній час у міжособистісних, інтерактивних стосунках простежуємо вияв неабиякої агресії. Необхідно, як видається, активізувати мовні засоби, що допоможуть iї нейтралізувати. Вияв агресії, негативних емоцій простежуємо в сучасних публіцистичних текстах, що актуалізовано як в англійській, так і в українській мовах.

Мета цієї статті - схарактеризувати засоби вираження негативних емоцій у публіцистичних текстах як дзеркалі довкілля, що разом 3 тим відображає й сучасні мовленнєві тенденції. Предмет дослідження - засоби вираження негативних емоцій у сучасних українсько- та англійськомовних публіцистичних текстах. Матеріалом статті слугують українські та англійські публіцистичні статті, опубліковані в газеті Украӥнська правда та журналі The New Yorker.

У вітчизняних та зарубіжних дослідженнях із психології існують різні думки щодо тлумачення категорії емочія. Американський психолог К. Ізард схиляється до думки, що „емоції утворюють первинну мотиваційну систему людини"з, а німецький психолог В. Вундт виділив тривимірний простір емоцій: „задоволення - незадоволення, збудження - спокій, напруження - розрядка"4. В. Шаховський стверджує, що для вираження однієї й тієї ж емоції люди використовують розмаїття мовних засобів ${ }^{5}$. Різноманітні емоції, виражені словами, зрозумілі всім носіям певної мови тільки тому, що ці емоції - певна форма сприйняття світу. Мова проникає у внутрішню структуру людських емоцій, лексикалізуючи та граматикалізуючи їх. Загальновідомим є й той факт, що людина частіше переживає негативні емоції, і мовних засобів для вираження негативної оцінки й негативних емоцій в кожній мові існує більше. Українці й росіяни здавна для цього використовували передусім прокляття під час сварки, що давали змогу зняти накопичення негативної енергії, запобігти стресу, вияву агресії́.

Важливим питанням лінгвістики емоцій є емоційний концепт як „етнічно, культурно зумовлене складне структурно-смислове, як правило, лексично та / або фразеологічно вербалізоване утворення, що базується на понятійній основі, охоплює, крім поняття, образ та оцінку, функціонально замінює людині в процесі рефлексії та комунікації безліч однопорядкових предметів, що викликають пристрасть як особливе ставлення до об'єктів довкілля"7. Першою важливою умовою появи емоційних концептів, що першочергово існують у понятій-

${ }^{1}$ T. Космеда, Ego i Alter Ego Tapaca Шевченка в комунікативному просторі щоденникового дискурсу, Дрогобич 2012, с. 49-55.

2 Див. про це докл.: Т. Космеда, Аксіологічні аспекти прагмалінгвістики: формування і розвиток категорії оцінки, Львів 2000.

${ }^{3}$ В. Д. С ліпецька, Прокляття як засіб репрезентаиії негативної комунікаиії, Харків 2011, c. 236-241. 2007.

${ }^{4}$ Див. про це докл.: Г. С. Кириленко, Психологія: емоційна сфера особистості, Київ

5 Див. про це докл.: В. Шахо вский, Эмоции: долингвистика, лингвистика, лингвокультурология, Москва 2010.

${ }^{6}$ В. Д. Слі іп ец ька, Прокляття як засіб репрезентаиії.., с. 236-241.

${ }^{7}$ Див. про це докл.: Н. А. Красавский, Эмоциональные концепты в немецкой и русской лингвокультурах, Москва 2008, с. 49. 
ній формі, М. Красавський уважає спільну колективну діяльність; наступною соціалізацію особистості - процес, що відбувається на пізнішому етапі еволюції цивілізації homo sapiens ${ }^{8}$. Етнічна специфіка емоційних концептів зумовлена традиціями, звичаями, особливостями побуту, стереотипами мислення, тобто тими соціо-психо-культурологічними характеристиками, що формуються впродовж історичного розвитку етнічної спільноти. „Емоційний концепт, зрозуміло, експлікується засобами мови". Реалізація кожного емоційного концепту здійснюється такими лінгвістичнимии способами, як:

1. Пряма номінація емоцій ${ }^{\mathbf{1 0}}$, напр., за допомогою іменників гнів, ненависть, страх, огида в українській мові; anger, hatred, fear, disgust, в англійській мові.

2. Безпосереднс вираження мовними засобами (вигуки, інвективи, брутальна лексика, пареміi) ${ }^{11}$.

Прямі номінації емоцій страху, гніву, ненависті та ін. охоплюють три лексико-граматичні класи:

a) іменники: fear, напр.: Fear of social ostracism, not to mention the perhaps pointless journey - the drive over the Throgs Neck Bridge ${ }^{12}$. Clinton noted the fears of Iran's neighbors ${ }^{13}$. Children starting ballet lessons are typically churning with desire and also with fear ${ }^{14}$. For companies, the fear of potential prosecution effectively raises the cost of doing business in high corruption countries, making it less likely that they will want to operate there at all ${ }^{15}$; anger, напр.: The previous assessment created consternation and anger inside the Bush Administration and in Congress $^{16}$; hatred, напр.: Boccassini has a personal hatred for him ${ }^{17}$; anxiety, напр.: ... allowing anxieties about the policies of a tyranial regime to distort our estimationof the states military capacity and intentions ${ }^{18}$. The general anxiety about the Iranian regime is firmly grounded ${ }^{19}$; contempt, напр.: There is a little contempt for the Artful Dodger, Italians evade paying taxes on a quarter of economy ${ }^{20}$; disgust, напр.: Disgust gave way to determined optimism ${ }^{21}$; Your mother shakes her hand in disgust ${ }^{22}$.

б) прикметники, що вживаються найчастіше 3 інфінітивом to be в англійській мові: to be afraid, напр.: Even after it's behind you and you have blocked her completely, you are still afraid you'll slip back to it ${ }^{23}$; stupid, напр.: After years of being told that smart managers succeeded and stupid managers failed ${ }^{24}$. He didn't like

${ }^{8}$ Там же, c. 50.

${ }^{9}$ Там же, с. 63 .

${ }^{10}$ В. Ш Ш хо в с ьк и й, Эмочии: долингвистика, лингвистика..., с. 22.

${ }^{11}$ Там же, с. 22.

${ }^{12}$ I. Frazier, Ghostly, [in:] ,The New Yorker”, New York 2011, June 6, p. 29.

${ }^{13}$ S. Hersh, Iran and the Bomb, [in:] ,The New Yorker”, New York 2011, June 6, p. 30-35.

${ }^{14}$ J. Acocella, Swandown, [in:] ,The New Yorker”, New York 2012, May 14, p. 40-42.

15 J. Surowiecki, Invisible Hand, Greased Palm, [in:] „,The New Yorker”, New York 2012 , May 14, p. 44.

${ }^{16}$ I. Frazier, Ghostly, [in:] ,The New Yorker”, New York 2011, p. 29.

${ }^{17}$ S. Hersh, Iran and the Bomb, [in:] „The New Yorker”, New York 2011, June 6, p. 34.

${ }^{18}$ Ibidem, p. 30.

${ }^{19}$ Ibidem, p. 30.

${ }^{20}$ A. Levy, Basta Bunga Bunga, [in:] „,The New Yorker”, New York 2011, June 6, p. 44-55.

${ }^{21}$ Ibidem, p. 50.

${ }^{22}$ J. Diaz, Miss Lora, [in:] „The New Yorker”, New York 2012, April 23, p. 63-67.

${ }^{23}$ J. Lepore, Battleground America, [in:] ,The New Yorker”, New York 2012, April 23, p. 39.

${ }^{24}$ L. MacFarquhar, When Giants Fail, [in:] „The New Yorker”, New York 2012, May 14, p.85-95. 
to call people stupid and, besides, the very same managers who were being called stupid today had been called geniuses last week, when the company was doing well and they were exactly doing what they were doing now ${ }^{25}$; silly, напр.: I'll just tell you a silly story to illustrate what's going on ${ }^{26}$; fool, напр.: [...] the best way to wish someone happy birthday without feeling like an exclamatory fool ${ }^{27}$; fearsome, напр/: The more fearsome wrong hands may be those of a malevolent regime ${ }^{28}$; angry, напр.: I was just so angry ${ }^{29}$; scary, напр.: The day after wasn't scary, it was a crap ${ }^{30}$; mynuй, дурний в українській мові, напр.: Не можна звинувачувати, щуо вони якісь тупі або дурні. Треба допомогти їм розібратися в ситуації̈ ${ }^{31}$ Наведені вище приклади прикметників в українській та англійській мовах засвідчують спалахи агресії, емоційні зриви мовців.

в) дісслова: to scare, to hate, to scream, напр.: He scared the crap out of $m e^{32}$; I hate to say that ${ }^{33}$; She would hate you - that they would all hate you! ${ }^{34}$; Someone screamed Duck ${ }^{35}$; Kids ran to the hall screaming ${ }^{36}$;ненавидimu, напр.: А що зробили ви? У вас 8-12 годинний робочий день на виивій роботі, ви ненавидите свого начальника і при цььому не готові нічого міняти у своєму житті? ${ }^{37}$.

В англійській мові вербалізація негативних емоцій ненависті, страху, оги$\partial u$ в сучасних публіцистичних текстах здійснюється "релігійними вигуками”, напр.: God! Oh, Jesus! ${ }^{38} ;$ My God! ${ }^{39}$.

Аналіз сучасних англійськомовних публіцистичних текстів засвідчує використання брутальної лексики як засобу вербалізації негативних емоцій гнівy, ненависті, напр.: There was his father, ripping into the opening bars of "Kiss my Glock," shooting rifles with Anthony Bourdain and not telling then Presidential candidate Barack Obama to "s*ck on one of these!"- a pair of machine guns.40.; It's the same old shit! ${ }^{41}$; You guys are all gay! We have the men who ${ }^{*}$ ck! ${ }^{42}$; One cannot appoint someone to be Minister of Equal Opportunity because she is $\boldsymbol{s}^{*}$ cking your $\boldsymbol{d}^{*} \boldsymbol{c k} !^{43}$; They said, the man would taunt Lidiya, calling her a f*ing $\boldsymbol{b}^{*} \boldsymbol{t c h}^{44}$;

${ }^{25}$ Ibidem, p. 85.

${ }^{26}$ Ibidem, p. 93.

${ }^{27} \mathrm{~T}$. Wayne, I'm the Article about the Internet that you Repost on the Internet, [in:] „The New Yorker", New York 2012, May 14, p. 67. p. 79.

${ }^{28}$ N. Paumgarten, Here's Loking at you, [in:] „The New Yorker”, New York 2012, May 14,

${ }^{29}$ E. Osnos, The Love Business, [in:] „,The New Yorker”, New York 2012, May 14, p. 76-82.

${ }^{30}$ J. Diaz, Miss Lora, [in:] „The New Yorker”, New York 2012, April 23, p. 63-67.

31 Д. Рогачук, Леонід Остальцев: Я хотів би жити в краӥні з громадянами, а не просто 3 мешканиями, [в:] Електронний ресурс: http://vybory.pravda.com.ua/articles/2018/02/6/7149562/ (06.02.2018).

${ }^{32}$ L. MacFarquhar, When Giants Fail, [in:] „The New Yorker”, New York 2012, May 14, p. $85-95$.

${ }_{33}^{3}$ J. Lepore, Battleground America, [in:] „The New Yorker”, New York 2012, April 23, p. 39.

${ }^{34}$ J. Diaz, Miss Lora, [in:] „The New Yorker”, New York 2012, April 23, p. 63-67.

${ }^{35}$ J. Lepore, Battleground America, [in:] „The New Yorker”, New York 2012, April 23, p. 39.

${ }^{36}$ Ibidem, p. 39.

${ }^{37}$ Д. Рогачук, Леонід Остальцев: Я хотів би жити в краӥні з громадянами...

${ }^{38} \mathrm{~T}$. Wayne, I'm the Article about the Internet that you Repost on the Internet..., p. 67.

${ }^{39}$ J. Lepore, Battleground America, [in:] „The New Yorker”, New York 2012, April 23, p. 39.

${ }^{40}$ R. Wiederman, Big Ted, Little Ted, [in:] „The New Yorker”, New York 2011, June 6, p. $26-27$.

${ }^{41}$ S. Hersh, Iran and the Bomb, [in:] „The New Yorker”, New York 2011, June 6, p. 31.

${ }^{42}$ A. Levy, Basta Bunga Bunga, [in:] ,The New Yorker”, New York 2011, June 6, p. 47.

${ }^{43}$ Ibidem, p. 52.

${ }^{44}$ S. Stillman, The Invisible Army, [in:] „The New Yorker”, New York 2011, June 6, p. 56-65. 
How did I end up on the bullshit-tech-story beat? ${ }^{45}$; You'd f*ck anything, someone geared $^{46}$; Even though he was a super asshole at the end ${ }^{47}$; His last $\boldsymbol{f}^{*}$ cking days and wouldn't say a word ${ }^{48}$; Not that she had huge ones like you chick was just wiry like a motherf*er, every single fibre standing out in outlandish definition ${ }^{49}$; That old $\boldsymbol{f}^{*}$ ing hag? That would be like f*ing a stick, she says. You'd better not f*ck her. Don't be a crazy person. I'm not $\boldsymbol{f}^{* i n g}$ anyone ${ }^{50}$; They should arrest that crazy bitch ${ }^{151}$.

Аналіз сучасних українськомовних публіцистичних текстів засвідчує використання брутальної лексики як засобу вербалізації негативних емоцій гніву, ненависті, напр.: Вибрали иього президента вони, вибирають депутатів вони. Вони ж і потакають їм, ніфіга не роблять. Натомість - сидять удома, обговорюють за пляшкою, які всі погані, і при цьому не виконують свій громадянський обов'язок. Навіть на вибори не йдуть, а якщо і йдуть, то думають сра* *о, а не головою ${ }^{52}$. Хто вибрав цих політиків? Вони уроди, я не заперечую. Але хочу, щоб люди теж зрозуміли, що й вони уроди. Саме вони довели нашу краӥну до такого стану. Ми отримали те, що заслужили, - ні більше, ні менше ${ }^{53}$. Дуже популярна думка, мовляв, „Усі політики апріорі під** и. Яж не під*p, тому просто не буду вникати в ию тему". Цим користуються ${ }^{54}$.

Використання брутальної лексики в сучасних публіцистичних текстах можна пояснити прагматичною настановою мовців на зняття накопичення негативної енергії, запобігти стресу, агресії. Залучення невербальних графічних знаків для вираження негативних емоцій у тексті зумовлює вияв прагматичних інтенцій ${ }^{5}$. На думку I. Арнольд, текст, що містить багато пунктуаційних знаків, уважається емоційним ${ }^{56}$. Результати аналізу сучасних англійських публіцистичних текстів засвідчують використання окличних речень для вербалізації негативних емоцій гніву, обурення, ненависті, напр.: Between mothers and daughters! Between grandparents and grandchildren! Aunts and their dentists! Stop using the word random incorrectly group! God, we are doomed as race! Twitter! Hashtags! Celebrities! Microcelebrities! How things have changed in the past six months! Athletes! Who cares! ${ }^{57}$. Використання знака оклику дає змогу відчути підвищену емоційність висловлювання. Невербальний графічний знак оклику увиразнює подання негативних емоцій гніву, ненависті.

Одним із засобів вираження негативних емоцій гніву, ненависті, огиди, без сумніву, є система орнаментальних засобів, серед яких передусім метафора, напр.: The longer the occupations lasts, and the larger the Arab and Palestinian populations grow in territory under Israeli control, the more untentable Israel's fu-

${ }^{45}$ T. Wayne, I'm the Article about the Internet that you Repost on the Internet..., p. 67.

${ }^{46}$ J. Diaz, Miss Lora, [in:] „The New Yorker”, New York 2012, April 23, p. 63.

${ }^{47}$ Ibidem, p. 63.

${ }^{48}$ Ibidem, p. 63.

${ }^{49}$ Ibidem, p. 63.

${ }^{50}$ Ibidem, p. 63.

${ }^{51}$ Ibidem, p. 63.

52 Д. Рогачук, Леонід Остальщев: Я хотів би жити в країні з громадянами...

${ }^{53}$ Там само.

${ }^{54}$ Там само.

${ }^{55}$ В. Д. С ліпець ка, Репрезентація негативних емоиій у писемному мовленні як стимул моделювання прагматичної пунктуачійної норми (на матеріалі аналізу творів I. НечуйЛевииького, М. Гоголя, Ч. Діккенса), [w:] „Studia Ukrainica Posnaniesia”, Poznań 2017, zeszyt V, s. $189-194$.

${ }^{56}$ И. В. Арн оль д, Семантика, стилистика, интертекстуальность, СПб. 1999, с. 233.

${ }^{57}$ T. Wayne, I'm the Article about the Internet that you Repost on the Internet..., p. 67. 
ture as both Jewish and democratic becomes. And tsunami approaches ${ }^{58}$. Oh, boy! There is just a tsunami of adventure cravings at that age $e^{59}$. He has still got this yawning chasm of thirty, forty years stretching out before him ${ }^{60}$. He imagined running into Woody Alen and Warren Beatty, inspired Brydon and Coogan to sing some lines from You are so vain, puzzling over the phrase clouds in my coffee ${ }^{61}$. King, shot in the head, fell face first onto the table, a pool of blood forming. A bullet grazed Mueller's ear ${ }^{62}$.

Дослідження українських публіцистичних текстів також засвідчує використання мовцями метафоричних перенесень найменувань гусак (гусь), козел, баран для вербалізації негативних емоцій гніву, ненависті, напр.: Якось я зустрічав на вокзалі командира своєї роти, а він у мене Герой Украӥни. До нас підійшов якийсь п'яний гусь, здоровий такий, $і$ каже: „От, я такий же, як $і$ ви, теж воював. Дайте мені грошей ${ }^{63}$.

У тролейбусі було кілька разів, коли п'яні гусі неправильно поводилися щзодо пасажирів чи кондуктора. То я теж не розмовляв, а одразу лупив.

Може, треба з себе починати? 3 власної голови почати зміни? А не кричати, щзо Порох, козел, прийшов у Pizza Veterano.

Ну і хто ви? Стадо баранів, а не люди. От цее мене бісить найбільше .

У сучасних українсько- й англійськомовних публіцистичних текстах спостерігаємо використання заперечних часток не, $\boldsymbol{\mu i}, \boldsymbol{n o}, \boldsymbol{n o t}$ як засобів вираження негативних емоцій гніву, обурення. Емотивною прагматичною настановою мовців є ліквідація накопичення негативної енергії. Повтор заперечних часток $\boldsymbol{\mu} \boldsymbol{e}, \boldsymbol{n o}, \boldsymbol{n o t}$ в одному реченні виконує емфатичну функцію. Унаслідок такої лексичної, граматичної та ритмічної побудови речень створюється ефект підвищення градусу емоційності в українсько- та англійськомовних публіцистичних текстах, напр.: No negotiations with a Palestinian political entity; no Palestinian refugees, no matter how few or how symbolic, to be admitted to Israel ${ }^{65}$. There is no alternative to doing so. He did not mention the current intelligence stating that there is no conclusive evidence that Iran is making any efforts to weaponizer; nor could he say that the current sanctions regime is aimed at forcing Iran to stop a nuclear weapons programme ${ }^{66}$. They did not issue a summary for public consumption ${ }^{67}$. But fact still remains that we do not know what we don't know ${ }^{68}$. There may or may not be weaponization in Iran today. Iran does not now have a nuclear weapon. Get off your no-enrichment policy, which is getting you nowhere. Stop your covert activities. Give the Iranians a sign that you're not pursuing regime change ${ }^{69}$. I do not get into the specifics in terms of Iranian demands ${ }^{70}$. If they need help we will be there to help them, but no more free ride ${ }^{71}$. We do not let people go and die in the street ${ }^{72}$. Don't

${ }^{58}$ R. Wiederman, Big Ted, Little Ted, [in:] ,The New Yorker”, New York 2011, June 6, p. 26.

${ }^{59}$ Ibidem, p. 26.

${ }^{60}$ M. Schulman, Buddies, [in:] ,The New Yorker”, New York 2011, June 6, p. 28.

${ }^{61}$ Ibidem, p. 29.

62 J. Lepore, Battleground America, [in:] ,The New Yorker”, New York 2012, April 23, p. 39.

${ }^{63}$ Д. Рогачук, Леонід Остальцев: Я хотів би жити в крайні з громадянами...

64 Там само.

${ }^{65}$ H. Hertzberg, O’bama vs. Netanyahoo, [in:] „The New Yorker”, New York 2011, June 6, p. $25-26$.

${ }^{66}$ S. Hersh, Iran and the Bomb, [in:] ,The New Yorker”, New York 2011, June 6, p. 30-35.

${ }^{67}$ Ibidem, p. 32.

${ }^{68}$ Ibidem, p. 31.

${ }^{69}$ Ibidem, p. 35.

${ }^{70}$ Ibidem, p. 35.

${ }^{71}$ R. Lizza, Romney's Dilemma, [in:] „The New Yorker”, New York 2011, June 6, p. 38-43.

${ }^{72}$ Ibidem, p. 40. 
assume that because he is a Republican governor he is not going to want an individual mandate ${ }^{73}$. Romney does not appear to have had many doubts. I do not think the Governor was opposed to it at all ${ }^{74}$. You could not hear from anybody - you did not know if they were scared ${ }^{75}$ ! No man? No problem! - it would be out of place in its previous location, on Wall Street ${ }^{76}$. Tax forms don't ask about gender, so it's not easy for the I. R. S. to decipher the legality of a marriage ${ }^{77}$;

Як наслідок, люди (практично все народонаселення Земної кулі) після проходження крізь жорнова класно-урочної системи: $\boldsymbol{H E}$ здатні протистояти гордині і жадібності своїх правителів; $\boldsymbol{H E}$ здатні дати відсіч націоналістичному або релігійному екстремізму своїх співвітчизників, якщо самі не стали носіям ичих інфекцій; $\boldsymbol{H E}$ здатні подолати свою байдужість або боягузливість, щзоб піднятись на захист моральних, культурних, історичних або інших иінностей, ідеалів, якщзо ичі ідеали якимось дивним чином проросли в їх душах, всупереч "напалму" класно-урочної системи; НE здатні ні інтелектуально, ні морально творити, будувати майбутнє, оскільки привчені бути мовчазними виконавцями чужсої волі; $\boldsymbol{H E}$ здатні розірвати кайдани давно застарілих традииій, вигаданих фобій $i$ забобонів, щзо крадуть у них їх свободи і гідність тощоо ${ }^{78}$.

Отже, засобами вираження негативних емоцій у сучасних українсько- та англійськомовних публіцистичних текстах слугують пряма номінація емоцій гніву, ненависті, обурення, вигуки, невербальний графічний знак оклику, метафоричні перенесення, брутальна лексика, заперечні частки нe, $h i, n o, n o t$, а також засоби орнаменталіки, серед яких найбільше виявляється метафора. Перспективу праці вбачаємо в аналізі агресивної метафори як засобу вербалізації негативних емоцій.

\section{Список використаної літератури}

Арнольд И. В., Семантика, стилистика, интертекстуальность, СПб. 1999.

Кандибур Г., Як школа інфікує пороками і особистісними рисами раба, [в:] Електронний ресурс: http://life.pravda.com.ua/columns/2018/02/7/228839/ (07.02.2018).

Кириленко Г. С., Психологія: емоційна сфера особистості, Київ 2007.

Космеда T., Ego i Alter Ego Tapaca Шевченка в комунікативному просторі щоденникового дискурсу, Дрогобич 2012.

Космеда Т., Аксіологічні аспекти прагмалінгвістики: формування і розвиток категорії оиінки, Львів 2000.

Красавский Н. А., Эмоциональные концепты в немецкой и русской лингвокультурах, Москва 2008.

Рогачук Д., Леонід Остальщев: Я хотів би жити в країні з громадянами, а не просто з мешканиями, [в:] Електронний ресурс: http://vybory.pravda.com.ua/ articles/2018/02/6/7149562/ (06.02.2018).

Сліпецька В. Д., Прокляття як засіб репрезентації негативної комунікаиії, [в:] „Лінгвістичні дослідження”, зб. наук. праць ХНПУ ім. Г. С. Сковороди, наук. ред. Л. А. Лисиченко, Харків 2011, вип. 32, с. 236-241.

Сліпецька В. Д. Репрезентація негативних емочій у писемному мовленні як стимул моделювання прагматичної пунктуаційної норми (на матеріалі аналізу творів

${ }^{73}$ Ibidem, p. 40.

${ }^{74}$ Ibidem, p. 41.

${ }^{75}$ A. Levy, Basta Bunga Bunga, [in:], ,The New Yorker”, New York 2011, June 6, p. 44-55.

${ }^{76}$ R. Wiederman, Tax Day, [in:] ,The New Yorker”, New York 2012, April 23, p. 20-21.

${ }^{77}$ Ibidem, p. 21.

${ }^{78}$ Г. Кандибур, Як школа інфікує пороками і особистісними рисами раба, [в:] Електронний pecypc: http://life.pravda.com.ua/columns/2018/02/7/228839/ (07.02.2018). 
I. Нечуй-Левицького, М. Гоголя, Ч. Діккенса), [w:] „Studia Ukrainica Posnaniesia”, Poznań 2017, zeszyt V, s. 189-194.

Шаховский В., Эмочии: долингвистика, лингвистика, лингвокультурология, Москва 2010.

Acocella J., Swandown, [in:] „The New Yorker”, New York 2012, May 14, p. 40-42.

Diaz J., Miss Lora, [in:] „The New Yorker”, New York 2012, April 23, p. 63-67.

Frazier I., Ghostly, [in:] „The New Yorker”, New York 2011, June 6, p. 29.

Hersh S., Iran and the Bomb, [in:] „The New Yorker”, New York 2011, June 6, p. 30-35.

Hertzberg H., O’bama vs. Netanyahoo, [in:] „The New Yorker”, New York 2011, June 6, p. 25-26.

Lepore J., Battleground America, [in:] „The New Yorker”, New York 2012, April 23, p. 39.

Levy A., Basta Bunga Bunga, [in:] „The New Yorker”, New York 2011, June 6, p. 44-55.

Lizza R., Romney's Dilemma, [in:] „The New Yorker”, New York 2011, June 6, p. 38-43.

MacFarquhar L., When Giants Fail, [in:] „The New Yorker”, New York 2012, May 14, p. 85-95.

Osnos E., The Love Business, [in:] „The New Yorker”, New York 2012, May 14, p. 76-82.

Paumgarten N., Here's Loking at you, [in:] „The New Yorker”, New York 2012, May 14, p. 79.

Schulman M., Buddies, [in:] „The New Yorker”, New York 2011, June 6, p. 28.

Stillman S., The Invisible Army, [in:] „The New Yorker”, New York 2011, June 6, p. 56-65.

Surowiecki J., Invisible Hand, Greased Palm, [in:] „,The New Yorker”, New York 2012, May 14, p. 44.

Wayne T., I'm the Article about the Internet that you Repost on the Internet, [in:] „The New Yorker", New York 2012, May 14, p. 67.

Wiederman R., Big Ted, Little Ted, [in:] ,The New Yorker”, New York 2011, June 6, p. $26-27$.

Wiederman R., Tax Day, [in:] „The New Yorker”, New York 2012, April 23, p. 20-21.

\section{Spysok vykorystanoi literatury \\ [References]}

Arnold Y. V., Semantika, stilistika, intertekstualnost' [Semantics, Stylistics, Intercontextuality], SPb. 1999.

Kandybur H., Yak shkola infikuie porokamy i osobystisnymy rysamy raba [How School Inficates Peculiar Features of Slave], [v:] Elektronnyi resurs: http://life.pravda.com.ua/columns/2018/02/7/228839/ (07.02.2018).

Kyrylenko H. S., Psykholohiia: emotsiina sfera osobystosti [Psychology: Emotional Sphere of Personality], Kyiv 2007.

Kosmeda T., Ego i Alter Ego Tarasa Shevchenka v komunikatyvnomu prostori shchodennykovoho dyskursu [Ego and Alter Ego of Taras Shevchenko in Communicative Space of Diary Discourse], Drohobych 2012.

Kosmeda T., Aksiolohichni aspekty prahmalinhvistyky: formuvannia i rozvytok katehorii otsinky [Axiological Aspects of Pragmalinguistics: Formation and Development of Estimation Category], Lviv 2000.

Krasavskij N. A., E'mocional'nye koncepty v nemeckoj i russkoj lingvokulturah [Emotional Concepts in German and Russian Linguo-Culture], Moskva 2008.

Rohachuk D., Leonid Ostaltsev: Ya khotiv by zhyty $v$ kraini z hromadianamy, a ne prosto $z$ meshkantsiamy [Leonid Ostaltsev: I"d Like to Live in Country with Citizens but not merely with Inhabitants], [v:] Elektronnyi resurs: http://vybory.pravda.com.ua/articles/2018/02/6/7149562/ (06.02.2018).

Slipetska V. D., Prokliattia yak zasib reprezentatsii nehatyvnoi komunikatsii [Cursings as Means of Negative Communication Representation], [v:] „Linhvistychni doslidzhennia”, zb. nauk. prats KhNPU im. H. S. Skovorody, nauk. red. L. A. Lysychenko, Kharkiv 2011, vyp. 32, s. 236-241.

Slipetska V. D., Reprezentatstsiia nehatyvnykh emotsii u pysemnomu movlenni yak stymul modeliuvannia prahmatychnoi punktuatsiinoi normy (na materiali analizu tvoriv 
I. Nechui-Levytskoho, M. Hoholia, Ch. Dikkensa) [Representation of Negative Emotions in Written Speech as Stimule of Pragmatic Punctuation Norm Modelling], [w:] „Studia Ukrainica Posnaniesia", Poznań 2017, zeszyt V, s. 189-194.

Shahovskij V., E’mocii: dolingvistika, lingvistika, lingvokul'turologiya [Emotions: Pre-Linguistics, Linguistics, Linguoculturology], Moskva 2010.

Acocella J., Swandown, [in:] ,The New Yorker”, New York 2012, May 14, p. 40-42.

Diaz J., Miss Lora, [in:] „The New Yorker”, New York 2012, April 23, p. 63-67.

Frazier I., Ghostly, [in:] „The New Yorker”, New York 2011, June 6, p. 29.

Hersh S., Iran and the Bomb, [in:] „The New Yorker”, New York 2011, June 6, p. 30-35.

Hertzberg H., O’bama vs. Netanyahoo, [in:] „The New Yorker”, New York 2011, June 6, p. 25-26.

Lepore J., Battleground America, [in:] „The New Yorker”, New York 2012, April 23, p. 39.

Levy A., Basta Bunga Bunga, [in:] „The New Yorker”, New York 2011, June 6, p. 44-55.

Lizza R., Romney's Dilemma, [in:] „The New Yorker”, New York 2011, June 6, p. 38-43.

MacFarquhar L., When Giants Fail, [in:] „The New Yorker”, New York 2012, May 14, p. 85-95.

Osnos E., The Love Business, [in:] „The New Yorker”, New York 2012, May 14, p. 76-82.

Paumgarten N., Here's Loking at you, [in:] „,The New Yorker”, New York 2012, May 14, p. 79.

Schulman M., Buddies, [in:] „The New Yorker”, New York 2011, June 6, p. 28.

Stillman S., The Invisible Army, [in:] „The New Yorker”, New York 2011, June 6, p. 56-65.

Surowiecki J., Invisible Hand, Greased Palm, [in:] „The New Yorker”, New York 2012, May 14, p. 44.

Wayne T., I'm the Article about the Internet that you Repost on the Internet, [in:] „The New Yorker", New York 2012, May 14, p. 67.

Wiederman R., Big Ted, Little Ted, [in:] „The New Yorker”, New York 2011, June 6, p. 26-27.

Wiederman R., Tax Day, [in:] „The New Yorker”, New York 2012, April 23, p. 20-21. 